\title{
症例報告
}

\section{腹腔鏡補助下に切除した無症候性結腸静脈型血管腫の 1 例}

\author{
木村 聡大 $^{1}$, 只野 惣介 $^{1}$, 物井 久 $^{1}$ \\ 1 茨城県常総市新井木町 13-3 きぬ医師会病院外科
}

\section{要 旨}

症例は 50 歳の男性で, 左側腹部痛を主訴に当院を受診した。腹部 CT で左尿管結石と共に偶発的に横行結腸の腫瘤性病 変を指摘された。結石の排石により側腹部痛は改善したものの, 下部消化管内視鏡検査では横行結腸に暗赤色調の粘膜下 腫瘤様の隆起性病変が認められ血管腫が疑われたため, 消化管出血や通過障害の出現を考慮し待機的に手術が施行された. 腹腔内を観察すると, 肝彎曲部付近の横行結腸に壁外から近傍の大網内まで進展する血管腫が認められたため, 腹腔鏡補 助下で病変部位を含めた横行結腸切除術が施行された.病理組織学的には, 増生した弾性線維を伴う静脈の増殖が認められ, 静脈型血管腫と診断された。 大腸血管腫の切除例は, 組織学的にはその大部分が海綿状血管腫であり, 多くが出血症状を 主とした症候性に診断される. 本症例のような静脈型血管腫は非常に稀であり, 若干の文献的考察を加えて報告する.

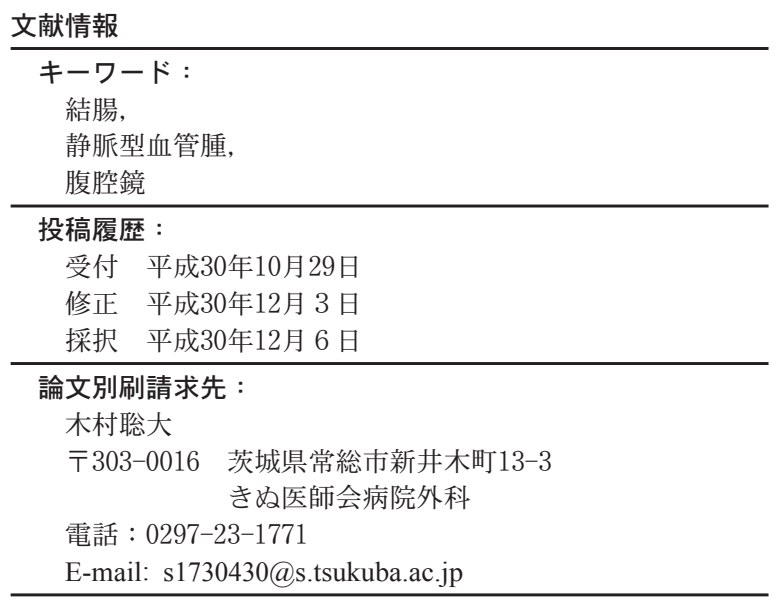

\section{緒言}

血管腫は軟部組織腫瘍の中では頻度の高い疾患である が, ${ }^{1}$ 消化管発生の血管腫は比較的稀であり, 全消化管腫 瘍のうち $0.05 \%$ を占めるに過ぎない. ${ }^{2}$ そのうち大腸発生 の頻度は 41 58\% と好発部位の一つであり, 病理組織学 的には大腸血管腫の大部分が海綿状血管腫と診断されてお り，その他の病型は非常に稀である. ${ }^{3,4}$ また，その多くは 下血や血便といった出血症状を発端として診断されてい る. ${ }^{5}$

今回, 我々は他疾患の発症を契機に偶発的に診断された 結腸静脈型血管腫の 1 例を経験したので, 若干の文献的考 察を加えて報告する.

\section{症例}

患 者 : 50 歳, 男性.

主 訴: 左側腹部痛.

既往歴 : 高血圧.

現病歴 : 左側腹部痛を主訴に当院を受診し, 腹部 CT で左 尿管結石および横行結腸の腫瘤性病変を指摘された。その 後, 尿管結石の排石に伴い側腹部痛は改善したが, 下部消 化管内視鏡検査で肝彎曲部付近の横行結腸に血管腫を指摘 された。出血や通過障害の可能性があることを説明し, イ ンフォームド・コンセントを得た上で手術を望まれたため, 手術目的に当科入院となった.

入院時現症：身長 $163.5 \mathrm{~cm}$, 体重 $53.3 \mathrm{~kg}$. 体温 $36.7{ }^{\circ} \mathrm{C}$, 血圧 144/94 mmHg, 脈拍 91 回 / 分, 整. 腹部は平坦, 軟. 眼瞼結膜に貧血認めず.

血液生化学検査所見：Hb $15.7 \mathrm{~g} / \mathrm{dl}$ と貧血は認めず。その 
他の血液検査所見にも特記すべき異常所見は認められな かった.

下部消化管内視鏡検査所見（図 1 ): 肝彎曲部近傍の横行 結腸に暗赤色調の粘膜下腫瘤様の隆起性病変が認められた. 鉗子での cushion sign は陽性であった。血管腫が疑われた ため生検は施行せず.

腹部造影 CT 所見 (図 2): 横行結腸に長径 $41 \mathrm{~mm}$ の多結 節状の造影効果に乏しい腫瘤が認められた。

手術所見 : 腹腔鏡で観察すると, 肝彎曲部近傍の横行結腸 に壁外から近傍の大網まで進展する血管腫が認められた。 その他の観察範囲内には血管腫は認められなかった．腹腔 鏡下で右半結腸を後腹膜より授動した後に, 小開腹をおい て病変部を体外に誘導し, 病変部を含む横行結腸および大 網を切除し, 機能的端端吻合で再建した。手術時間は 1 時 間 55 分, 出血量は $10 \mathrm{ml}$ であった.

切除標本肉眼所見（図 3): 腸管内腔に突出するような 36 $\times 24 \mathrm{~mm}$ の表面平滑で一部顆粒状の暗赤色調の隆起性病 変が認められた。

病理組織学的検查所見（図 4): 肉眼的病変部位に一致し て粘膜直下から漿膜下層まで内腔が比較的広く不規則な静 脈が増生していた，血管壁は比較的厚く，壁内に平滑筋束 が認められ, Elastica van Gieson 染色（EVG 染色）では著 明に濃縮，増生した弾性線維ないし弾性線維束が認められ た.

以上より，横行結腸静脈型血管腫と診断した. 術後経過：明らかな術後合併症は認めず, 術後 9 日目に退 院した.

考察

消化管血管腫は一般に先天的な血管異常によるものが多 いとされており, 内皮細胞の turnover は正常であり細胞 自体の増殖性は認めず, 血管腫を構成する血管自体の拡張 等により増大を呈するため, 新生物というよりは先天性血 管奇形に属する疾患と考えられている. ${ }^{6-8}$ 病理学的分類と しては, 構成される血管の種類・形状・壁の厚さなどに応 じて様々な分類がなされているが，(1) Multiple phlebectasia (2) Cavernous hemangioma (3) Simple capillary hemangioma (4) Angiomatosis with gastrointestinal lesion の 4 型に分 ける Kaijser9 の分類や (1) Capillary hemangioma (2) Mixed capillary and cavernous hemangioma (3) Cavernous hemangiomaの 3 型に大別する Gentry ${ }^{4}$ の分類が頻用されている. いずれの分類上でも頻度としては海綿状血管腫（Cavernous hemangioma）がその大部分を占めるが，稀な病型な らびに消化管に発生し得ない病型は上記の分類には含まれ ておらず, 具体的には本症例における静脈型血管腫の他に も，蔓状血管腫，肉芽組織型血管腫，類上皮性血管腫，房 状血管腫, 糸球体様血管腫, 鋲釘状血管腫, 紡錘形細胞型

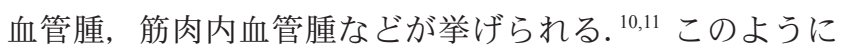

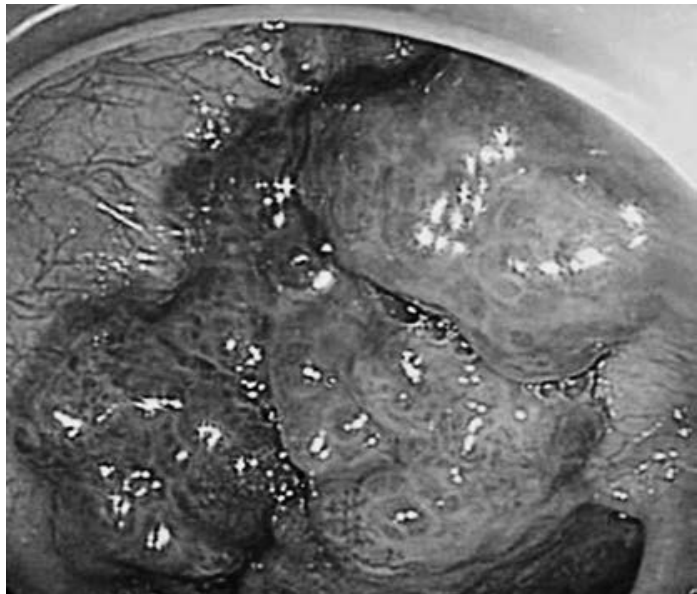

図 1 下部消化管内視鏡所見 : 肝彎曲部近傍の横行結腸に暗赤 色の粘膜下腫瘤様の隆起性病変が認められた。

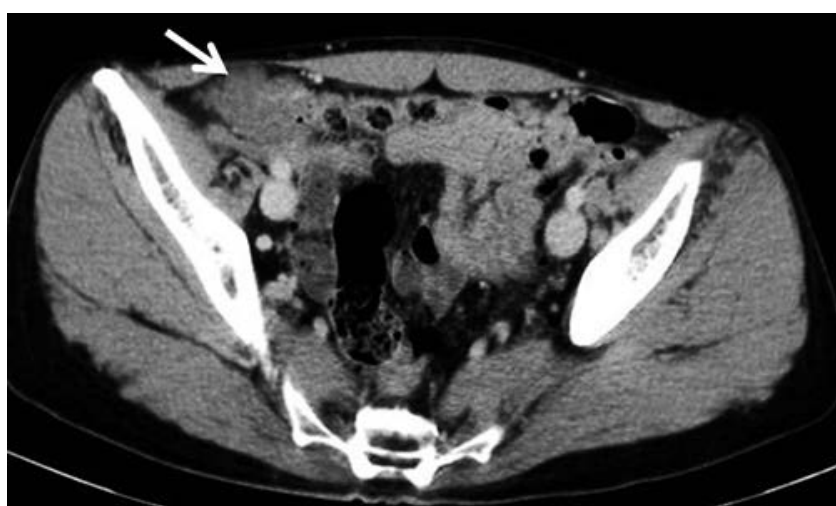

図 2 腹部造影 $\mathrm{CT}$ 所見：横行結腸に長径 $41 \mathrm{~mm}$ の多結節状 の造影効果に乏しい腫瘤（矢印）が認められた.

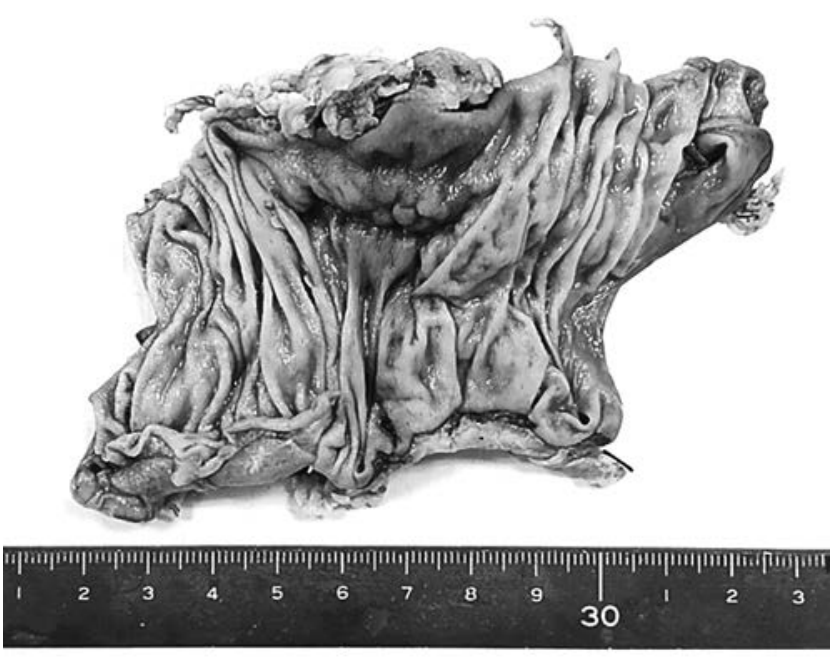

図 3 切除標本肉眼所見 : $36 \times 24 \mathrm{~mm}$ の表面平滑で一部顆粒 状の暗赤色調の隆起性病変が認められた.

血管腫はその病理組織学的所見以外にも構成成分や発生箇 所などに応じて様々な名称が使用されているが，近年血管 奇形に関する主要な国際学会である International Society for the Study of Vascular Anomalies (ISSVA）による分類 ${ }^{12}$ においては，その構成成分に基づいて従来的な海綿状血管 

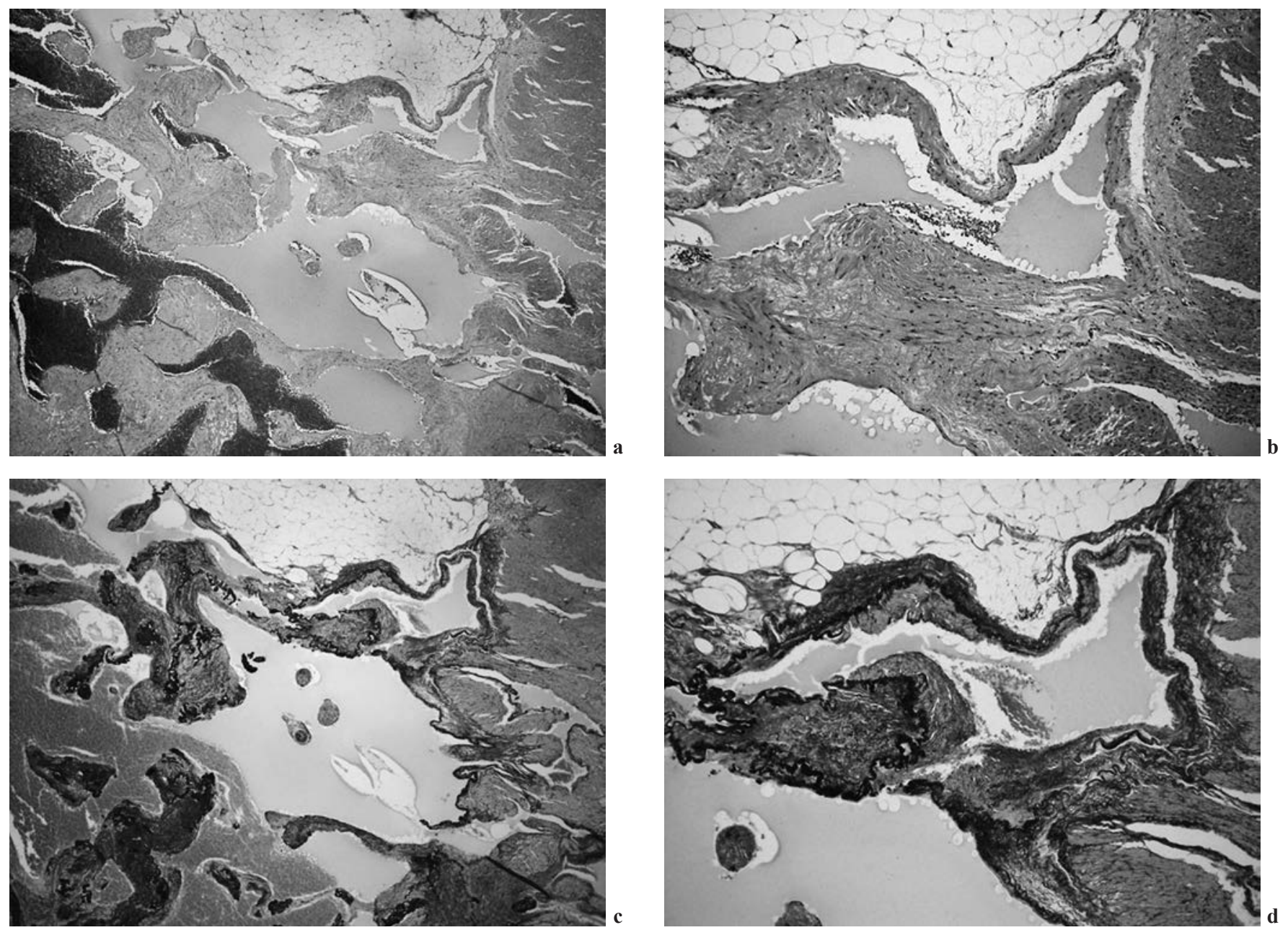

図 4 病理組織学的検査所見：内腔が比較的広く不規則な静脈が増生していた. EVG 染色では壁内に平滑筋束が認められ, 著明 に濃縮, 増生した弾性線維ないし弾性線維束を伴っていた. (a：HE 染色 $\times 40$ 倍, b : HE 染色 $\times 100$ 倍, c : EVG 染色 $\times$ 40 倍, $\mathrm{d}$ : EVG 染色 $\times 100$ 倍)

表 1 本邦報告の大腸静脈型血管腫のまとめ

\begin{tabular}{|c|c|c|c|c|c|c|c|c|}
\hline 症例 & 報告者 & 報告年 & 年齢/性別 & 主訴 & 内視鏡所見 & 大きさ & 部位 & 治療 \\
\hline 1 & 鳥 ${ }^{14)}$ & 1994 & 46/女 & タール便 & $\begin{array}{l}\text { 青白色調のポリープ性 } \\
\text { 病変 }\end{array}$ & $8 \mathrm{~mm}$ & $\begin{array}{l}\text { 上行結腸, } \\
\text { 空腸, 食道 }\end{array}$ & $\begin{array}{l}\text { 結腸部分切除術, 空腸部渞 } \\
\text { 部分切除術, 下部食道 } \\
\text { 部分切除術 }\end{array}$ \\
\hline 2 & 和城15) & 2011 & 58/男 & 便潜血陽性 & $\begin{array}{l}\text { 白色から赤色調の分葉 } \\
\text { 状隆起性病変 }\end{array}$ & $25 \times 20 \mathrm{~mm}$ & $\begin{array}{l}\text { 下行結腸, } \\
\text { 腸間膜 }\end{array}$ & $\begin{array}{l}\text { 下行結腸部分切除術, } \\
\text { 腸間膜部分切除術 }\end{array}$ \\
\hline 3 & 中島16) & 2018 & 82/男 & 下血 & $\begin{array}{l}\text { 大小様々な暗赤色調の } \\
\text { 隆起性病変 }\end{array}$ & びまん性 & $\begin{array}{l}\text { 下行結腸 } \\
\mathrm{S} \text { 状結腸 }\end{array}$ & $\begin{array}{l}\text { 腹腔鏡補助下結腸左半 } \\
\text { 切除術 }\end{array}$ \\
\hline 4 & 自験例 & 2018 & 50/男 & なし & $\begin{array}{l}\text { 暗赤色調の粘膜下腫瘤 } \\
\text { 様の隆起性病変 }\end{array}$ & $36 \times 24 \mathrm{~mm}$ & 横行結腸 & $\begin{array}{l}\text { 腹腔鏡補助下横行結腸 } \\
\text { 部分切除術 }\end{array}$ \\
\hline
\end{tabular}

腫や本症例のような静脈型血管腫などを venous malformation として統合している. しかしながら, 稀な病態を理解 していくうえではISSVA 分類における venous malformation も病理組織学的所見によっては更に細分類化できる事 を認識すべきである.

静脈型血管腫は, 一般的には成人四肢の皮下や深部軟部 組織を好発部位としており, ${ }^{1,10,11}$ 前述した海綿状血管腫と の混合型を呈する場合もあり判別が困難な場合もある. ${ }^{13}$ その病理学的特徵は, 海綿状血管腫と比較して血管の密度,
拡張の程度にばらつきが大きい中等度大以上の平滑筋被覆 を有する静脈からなり，しばしば間質中にも弾性線維ない し弾性線維束の増生を伴う点である. ${ }^{10,11,13}$ 故に詳細な診断 を得るには, EVG 染色やVictoria Blue 染色といつた特殊 染色による弾性線維の増生を同定する必要がある.

大腸発生の静脈型血管腫は極めて稀であり, 医学中央雑 誌で「大腸」,「結腸」,「直腸」,「血管腫」（会議録を除く）を キーワードに 1987 年から 2018 年までを検索した結果, 本 邦における大腸静脈型血管腫の報告は本症例を含めわずか 
4 例14-16 であつた（表 1)。検索の際には, 病態の異なる遺 伝性の消化管血管腫を合併する皮膚血管腫疾患としての blue rubber bleb nevus syndrome は除いた. 発症年齢は平 均 59 歳 (46 歳 8 8 歳) で, 男性が 3 例で女性が 1 例であっ た. 大腸血管腫の臨床症状としては, 冨田ら, ${ }^{17}$ 藤本ら ${ }^{18}$ の集計によると下血や血便という消化管出血症状が大部分 であり, 無症状で偶発的に診断されるのは $8.0 \sim 14.8 \%$ に 過ぎない. 海綿状血管腫より静脈型血管腫の方が出血しや すいとの報告もあるが, ${ }^{14}$ 未だ症例数が限られているため その傾向は明らかとは言えない. 今回検索した限りでは本 症例のように無症状で偶発的に診断される大腸静脈型血管 腫の報告は本邦で初めてである. 大腸血管腫の好発部位は 直腸, $\mathrm{S}$ 状結腸が過半数以上を占めているが, ${ }^{17,18}$ 今回集計 した静脈型血管腫の症例においては下行結腸から $\mathrm{S}$ 状結 腸までびまん性に存在していたものが 1 例認められたのみ で, その他は上行結腸, 横行結腸, 下行結腸を主座とする 症例が 1 例ずつと一般的な好発部位とは合致しない症例が 多かった. 内視鏡所見としては, 大腸血管腫は表面平滑な 粘膜下腫瘍として通常観察されることが多く, 血液の貯留 に応じて暗青色や暗紫色あるいは暗赤色調といつた色調を 呈するため, その特徵的な肉眼所見が認められれば診断は 比較的容易である. ${ }^{17,18}$ また, 鉗子圧迫で表面が柔らかく 陥凹する cushion sign も特徵的である. ${ }^{19}$ 一方で, 内腔に 突出するような単発の粘膜下腫瘍あるいはポリープ状の形 態を呈するものや, 色調としても白色や大腸粘膜と同色を 呈するものは診断が困難である. しかしながら生検は出血 の危険性があるため一般的には禁忌とされており, 内視鏡 検査以外の有用なモダリティとして脂肪抑制 $\mathrm{MRI}^{20}$ や腹 部血管造影 ${ }^{21}$ に関する報告もみられる. 本症例を含めた静 脈型血管腫においては, その肉眼所見は一般的な粘膜下腫 瘍様のものからポリープ状のものまで様々であったが, そ の肉眼的形態から全例において術前に血管腫と診断されて いる.

大腸血管腫は良性疾患であり, 検索した限りでは悪性転 化の報告はなく, 完全切除による予後は良好と考えられる. しかしながら, 多発性病変や残存病変による異時性の再燃 も認め得るため, ${ }^{14}$ 病変の多発性, 部位, 広がりを十分に 考慮したうえでの外科的切除が根本的治療とされている. ${ }^{6}$ また近年では, その易出血性を考慮してベッセルシーリン グデバイスを用いることで安全に腹腔鏡下でのアプローチ が可能であるとの報告もある. ${ }^{16}$ 更には, 内視鏡的切除の 報告数も増加してきており, 長田ら ${ }^{22}$ は(1)大きさが $2.5 \mathrm{~cm}$ 以下(2)有茎性もしくは亜有茎性(3)超音波内視鏡検査で粘膜 下層までに限局している病変を内視鏡的切除の適応として 挙げている.

大腸血管腫は有症状であっても保存的治療が可能であっ た報告も認められるが, ${ }^{23}$ 基本的には治療介入がない限り 自然退縮や消失は呈さないと考えられており, 7,8 中長期的 に出血を繰り返したり, ${ }^{24}$ 増大傾向を認めたりしたもの ${ }^{17}$
もあるため, 厳重な経過観察ならびに適切な時期での治療 介入が要される. 本症例においては, 診断時には無症状で あり, 出血や通過障害の出現を考慮して十分なインフォー ムド・コンセントを得た上での外科的切除がなされている が，大腸血管腫の中でも殊更稀な病型である静脈型血管腫 を長期間経過観察した症例はなく，更なる症例の集積が望 まれる。

利益相反：なし

\section{文献}

1. Weiss SW, Goldblum JR. Benign tumors and tumor-like lesions of blood vessels. In: Weiss SW, Goldblum JR (eds). Enzinger and Weiss's Soft Tissue Tumors, 5th edition, Mosby Elservier, Philadelphia, 2008, 633-680.

2. Boyle L, Lack EE. Solitary cavernous hemangioma of small intestine. Case report and literature review. Arch Pathol Lab Med 1993; 117: 939-941.

3. 谷・ロベルト・ダニエル, 谷口徹志, 神津照雄ら. 大腸海 綿状血管腫のポリペクトミーによる 1 治験例. Gastroenterological Endoscopy 1983; 25: 1407-1412.

4. Gentry RW, Dockerty MB, Glagett OT. Vascular malformations and vascular tumors of the gastrointestinal tract. Surg Gynecol Obster 1949; 88: 281-323.

5. 本田亮一, 下島裕寛, 松本浩他ら。下血を主訴とした $\mathrm{S}$ 状 結腸血管腫と 2 型盲腸癌を併発した 1 例. 日本大腸肛門病 学会雑誌 2003; 56: 234-238.

6. 細田四郎, 佐々木雅也：腸血管腫瘍（血管腫, 腸毛細血管腫, 腸海綿状血管腫, 腸血管肉腫)。別冊日本臨牀, 6, 消化管 症候群 (下巻), 日本臨牀社, 大阪, 1994, 440-442.

7. 血管腫・血管奇形・リンパ管奇形診療ガイドライン 2017. http : //www.marianna-u.ac.jp/va/files/vascular \%20anomalies \% 20practice\%20guideline \%202017.pdf（2018 年 9 月 3 日)

8. Fernandez-Pineda I. Vascular tumors and malformations of the colon. World J Gastroenterol 2009; 15: 5242-5243.

9. Kaijser R. Uber hemangiome des tractus gastrointestinalis. Arch Klin Chir 1936; 187: 351.

10. 橋本洋. 血管・リンパ管内皮細胞の腫瘍および腫瘍状病変. 向井清, 真鍋俊明, 深山正久編, 外科病理学, 第 4 版, 文 光堂, 東京, 2006, 1554-1558.

11. Petras RE. Nonneoplastic Intestinal Diseases. In: Mills SE, Greenson JK, Hornick JL, et al (eds), Sternberg' s Diagnostic Surgical Pathology, 6th edition, Wolters Kluwer, Philadelphia, 2015, 1482-1483.

12. ISSVA Classification of Vascular Anomalies. http://www. issva.org/UserFiles/file/ISSVA-Classification-2018.pdf (2018 年 12 月 4 日)

13. Yang GZ, Li J, Jin H. Giant mesenteric hemangioma of cavernous and venous mixed type: a rare case report. BMC Surg 2013; 13: 50.

14. 鳥 正幸, 濱路政靖, 奥村賢三ら. 皮膚病変を伴わない 消化管多発性血管腫の 1 例. 日本臨床外科学会雑誌 1994; 55: 1880-1885. 
15. 和城光庸, 片倉 達, 熊谷信平ら. 腸間膜海綿状血管腫 を合併した結腸静脈型血管腫の 1 例. 日本臨床外科学会雑 誌 2011; 72: 126-129.

16. 中島千代, 吉本裕紀, 川本浩史ら. 腹腔鏡補助下に切除 した広範大腸静脈型血管腫の 1 例. 日本内視鏡外科学会雑 誌 2018; 23: 219-223.

17. 冨田 裕, 芹澤 宏, 渡辺憲明ら. 長期観察にて増大傾 向を認め外科切除に至った大腸血管腫の 1 例. Gastroenterological Endoscopy 1997; 39: 2409-2414.

18. 藤本浩一, 大西 始, 山本康久ら. 潰瘍性大腸炎の経過 中に発見された $\mathrm{S}$ 状結腸の毛細血管腫の 1 例. 日本大腸 肛門病学会雑誌 2010; 63: 434-439.

19. 近藤健司, 浜田 勉, 北村成大ら. 大腸びまん性海綿状 血管腫の 1 例. 胃と腸 1999; 34: 917-921.
20. 名和誉敏, 吉原治正, 山田幸則ら，脂肪抑制 MRI により 血管構造が明瞭に描出された直腸びまん性海綿状血管腫の 1 例. Gastroenterological Endoscopy 2008; 50: 1304-1310.

21. 森田 穣, 篠原正裕, 石川清文ら. 腫瘤の自然排出をみ た横行結腸血管腫の 1 例一その血管造影像を中心として一. 臨床放射線 1979; 24: 311-314.

22. 長田祐二, 藤森俊二, 南定ら.内視鏡的ポリペクトミー を施行した大腸海綿状血管腫の 1 例. Progress of Digestive Endoscopy（消化器内視鏡の進歩） 1992; 40: 349-352.

23. 井上善之, 高野眞寿, 鎌田晶義ら. 直腸びまん性血管腫 の 1 例. 胃之腸 2000; 35: 823-829.

24. 伊藤正郎, 加瀬 肇, 下山修ら. 人工肛門造設後 48 年目に, 頻回の下血のため手術を施行した大腸びまん性海綿状血管 腫の 1 例. 日本大腸肛門病学会雑誌 $2011 ; 64: 78-82$. 


\title{
A Case of Asymptomatic Venous Hemangioma of the Colon Resected under Laparoscopic Assisted Surgery
}

\author{
Sota Kimura ${ }^{1}$, Sosuke Tadano ${ }^{1}$ and Hisashi Monoi ${ }^{1}$ \\ 1 Department of Surgery, Kinu Medical Association Hospital, 13-3 Araigi-machi, Joso, Ibaraki 303-0016, Japan
}

\section{Abstract}

A 50-year-old man was admitted to our hospital complaining of left flank pain. Computed tomography revealed a left ureterolith and also an incidental mass in the transverse colon. Although the flank pain subsided after spontaneous passage of ureterolith, colonoscopy revealed a dark red protruding lesion in the transverse colon mimicking a submucosal tumor, which was a suspicion for hemangioma. To prevent bleeding and obstruction caused by the lesion, we performed elective surgery. Intraoperatively, there was an extramural hemangioma extending into the adjacent omentum in the transverse colon near the hepatic flexure. We performed partial resection of the transverse colon under laparoscopic assistance to include the whole lesion. Histopathological examination showed proliferation of veins with hyperplasia of elastic tissues. The lesion was diagnosed as a venous hemangioma. In the past reports, the majority of colonic hemangiomas were histopatholigically classified as cavernous hemangiomas. Most of these were symptomatic, with the most frequent symptom being intestinal bleeding. We report an extremely rare case of venous hemangioma, which was diagnosed incidentally.

\footnotetext{
Key words:

colon,

venous hemangioma,

laparoscopy
} 